\title{
Two new species of Bakerius from the Amazon Basin (Homoptera: Aleyrodidae)
}

\author{
Abstract \\ Two new species of Bakerius are described and \\ comparisons are made with their nearest relatives.
}

\section{INTRODUCTION}

In Aleyrodideos do Brasil, Bondar (1923) described the new genus Bakerius of the subfamily Aleurodicinae. Adults are characterized as having wings with complete venation ( $R$, $\mathrm{Rs}, \mathrm{M}$ and $\mathrm{Cu}$ ), antennae with seven segments, and forewing (tegmen) elongate and without concave indentations along the anal margin. Bondar described three species in his new genus. In 1928, he added three more species of Bakerius, and in 1938 Hempel added one more. With the addition of the present two new species, the genus Bakerius contains nine species listed below.

Bakerius amazonicus, n.sp. - Brazil (Amazonas)

\author{
Norman D. Penny (") \\ Jorge R. Arias (")
}

\author{
Bakerius attenuatus Bondar, 1923 - Brazil \\ (Bahia) \\ Bakerius calmoni Bondar, 1928 - Brazil \\ Bakerius conspurcatus (Enderlein), 1909 - Bra- \\ zil (Santa Catarina) \\ Bakerius glandulosus Hempel, 1938 - Brazil \\ (São Paulo) \\ Bakerius maculatus, n. sp. - Brazil (Amazo- \\ nas) \\ Bakerius phrygilanthi Bondar, 1923 - Brazil \\ (Bahia) \\ Bakerius sanguineus Bondar, 1928 - Brazil \\ (Bahia) \\ Bakerius sublatus Bondar, 1928 - Brazil (Bahia)
}

Although various authors have stated that species of Aleyrodidae can only be separated by the nymphs, these statements refer primarily to species of the much larger subfamily Aleyrodinae. We feel that adult characteristics are clear and distinctive in this and several other genera of Aleurodicinae. Adults of known species of Bakerius can be separated by the following key.

\section{KEY TO ADULTS OF BAKERIUS}

1a. Hindwings bearing distinctive spots (Fig. 6, 9-14) $\ldots \ldots \ldots \ldots \ldots 2$

1b. Hindwings without distinctive spots (Fig. 1-5) ............. B. maculatus $\mathrm{n} . \mathrm{sp}$.

2a. Forewing bearing only small, distinctive spots (Fig. 9-11) ..... 3

2b. Forewing bearing diffuse spots and clouded areas (Fig. 6, 12-14) .. 6

3a. In forewing, only one spot between R and Rs (Fig. 9) ......... B. calmoni Bondar

3b. In forewing, two spots between $R$ and Rs (Fig. 10, 11) ....... 4

4a. In forewing, basal costal spot isolated from margin (Fig. 10) .... B. sublatus Bondar

4b. In forewing, basal costal spot contiguous with margin (Fig. 11) ... 5

5a In hindwing, eight spots present; forewing length less than $1.9 \mathrm{~mm}$

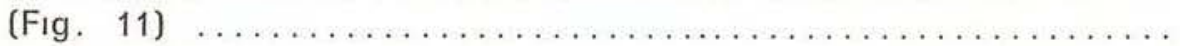

5b. In hindwing, seven spots present; forewing length more than $2.0 \mathrm{~mm}$

6a. In forewing, complete apical band and subapical band from $\mathrm{R}$ to

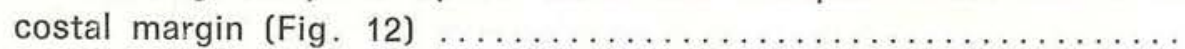
B. attenuatus Bondar
B. glandulosus Hempel
B. phrygilanthi Bondar

(") - Instituto Nacional de Pesquisas da Amazônia, Manaus. 
6b In forewing, apical band interrupted and subapical band appearing as spot between $R$ and costal margin (Fig. 6, 13, 14) $\ldots \ldots \ldots \ldots, 7$

7a. In forewing, basal half of costal area without spots, and without

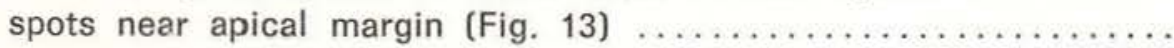

7b. In forewing, basal half of costal area bearing spots, and spots at or near apical margin (Fig. 6, 14) ....................... 8

8a In forewing, four large spots between $R$ and $M$; in hindwing only

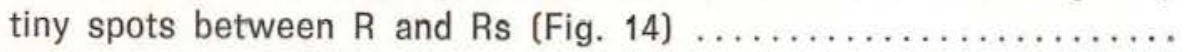

8b. In forewing, only one large and two intermediate sized spots between

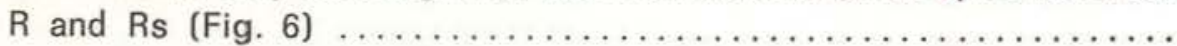

B. conspurcatus (End.)

B. sanguineus Bondar

B. amazonicus n. sp.
Bakerius maculatus Penny \& Arias, n. sp. (Fig. 1-5)

Description based on 1 male, 1 female on slides and 1 male in alcohol. Holotype male and allotype female in the Systematic Entomology Collections of INPA, Manaus. Paratype male in the U.S. National Museum, Washington, D.C., U.S.A.

Head: Acutely angular in dorsal aspect. Vertex not elevated above eyes, color creamy white with dark fuscous anterior border. Ocelli near compound eyes on occiput, clear with fuscous border. Compound eyes large, dark fuscous, strongly emarginate anteriorly. Antennae consisting of small, quadrate, pale yellow scape; rectangular, pale yellow pedicel; and five long, thin flagellar segments. Frons bulbously inflated, pale yellow. Rostrum three-segmented; attaining base of forelegs; pale yellow, except extreme tip dark fuscous.

Thorax: Pronotum collar-like, pale yellow. Scutum of mesonotum consisting of anteriolateral, pale yellow lobes and posterio-lateral, pale yellow tegulae. Medial lobes of mesoscutum heart-shaped, pale yellow; anterior lobe and hourglass-shaped posterior lobe, pale yellow. Sulcus between medial lobes of mesonotum a v-shaped line. Mesoscutellum fiat, triangular, pale yellow. Metanotum of two, quadrate, depressed, pale yellow sclerites. Meso and metapleura pale yellow.

Legs: Pale yellow, basally grouped close together; coxae large. Two tarsal segments; first about twice as long as second segment in males, of equal length in female.
Tegmen (Forewing): About twice as long as wide, without concave sculpting of any sort. Radius ( $R$ ) and radial sector (Rs) veins complete. Male with auxillary crossvein between $R$ and costal margin. Media (M) complete, reaching apical margin of wing. Cubitus $(\mathrm{Cu})$ present as clear line from wing base to anal margin. Anal vein apparently absent. Base color pale yellow; four fuscous maculations along costal margin; one fuscous maculation between R and Rs; three fuscous maculations along anal margin.

Hindwing: R, Rs and faint indication of $\mathrm{M}$; pale yellow; without maculations.

Abdomen of Male: Seven abdominal segments, pale yellow; dark orange marking ventrally on segment II and laterally at base of segment VII. Caudal margin of segment VI with strong spine ventrally, without knob dorsally. Segment VII with rasied knob dorsally at mid-length, pale fuscous. External male genitalia consisting of two long, lateral lobes, tapering to acute, inwardly-pointed terminal points; color pale yellow. Median genital filament short, thin, yellowish; curved dorsally.

Abdomen of Female: Seven pale yellow abdominal segments closely grouped together. Ventral spine terminal, upturned.

Body Length: Male, $4.0 \mathrm{~mm}$ (excluding genital lobes); female, $2.8 \mathrm{~mm}$.

Tegmen Length: Male, $3.2 \mathrm{~mm}$; female, 3.0 $\mathrm{mm}$.

Variation: Males have an auxillary crossvein between $\mathrm{R}$ and costal margin, which is missing in the female. There is also sexual dimorphism 


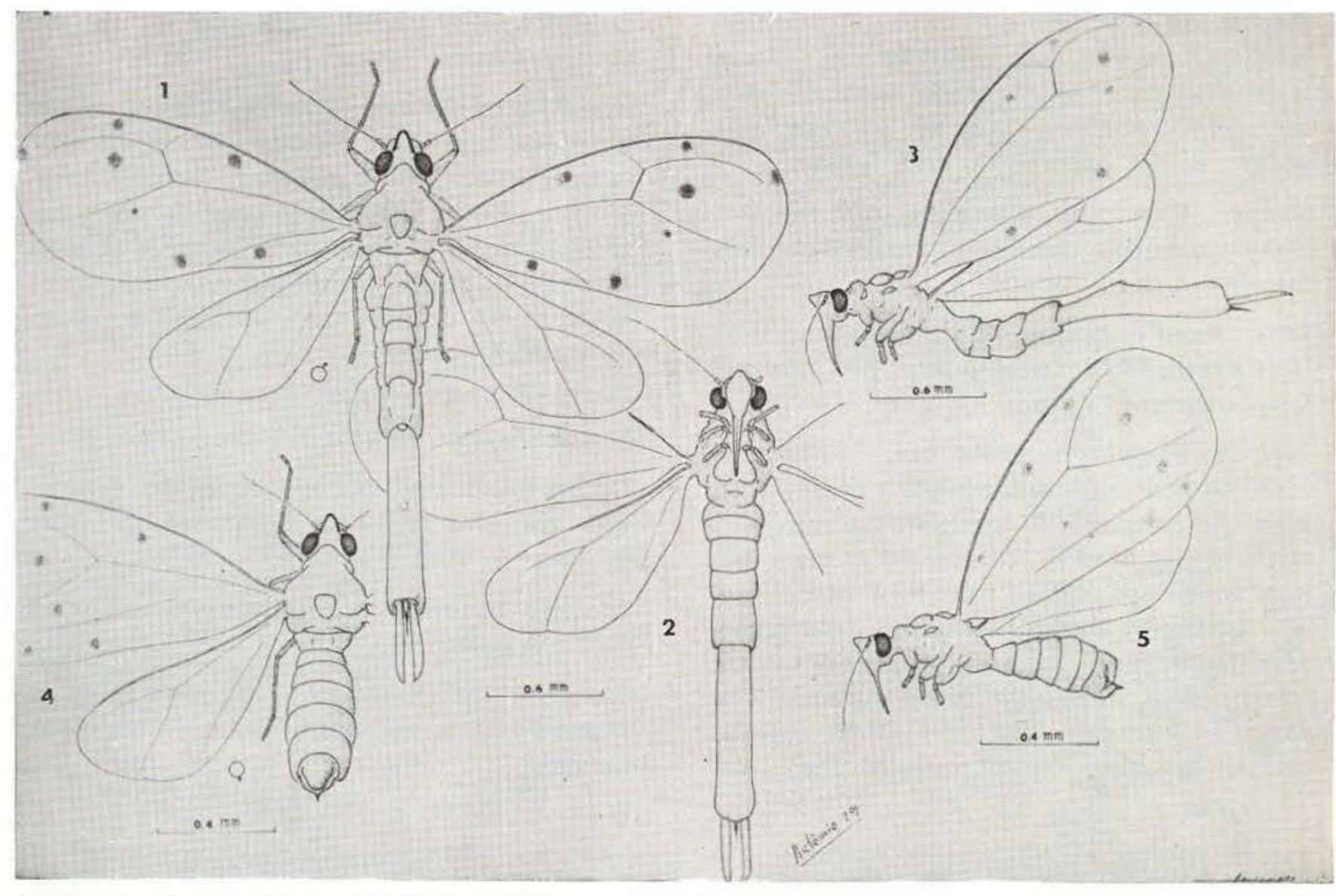

Fig. 1-5: Bakerius maculatus n. sp.: 1) - Dorsal view of maie; 2) -. Ventral view of male; 3) - Lateral view of male; 4) - Dorsal view of female; 5) - Lateral view of female.

in wing maculations and in the length of the second tarsal segment, when compared with the first segment.

Geographical Distribution: Holotype and paratype males were both collected at

Brazil: Amazonas, Manaus, by Jorge R. Arias, The allotype female was collected at

Brazil: Amazonas, $60 \mathrm{~km}$ north of Manaus, by Norman D. Penny.

Temporal Distribution: Holotype male and allotype female were collected on 11 and 9 Oct. 1979 , while the paratype male was collected on 23 Oct. 1979, indicating a possible October emergence of this species.

Ecclogy: The holotype and paratype males were taken from a Malaise trap in secondary forest on the INPA campus. The allotype was collected with an aerial net on understory vegetation in a primary forest.
Bakerius maculatus appears to be most closely related to B. attenuatus Bondar and other spotted-winged species, but differs from all others by the lack of spots on the hindwings. The name maculatus comes from the Latin word meaning spot, referring to the wing maculations.

Bakerius amazonicus Penny \& Arias, n. sp. (Fig. 6-8)

Description based on 1 female on a slide. Holotype deposited in the Systematic Entomology Collections of INPA, Manaus.

Head: Acutely angular in dorsal aspect. Vertex not elevated above eyes, pale yellow with dark fuscous anterior border. Compound eyes large, dark fuscous, strongly emarginate anteriorly. Ocelli near compound eyes on occiput, clear with fuscous border. Antennae consisting of small, quadrate, pale yellow scape; e- 
longate, pale yellow pedicel and five thin, elongate, pale yellow flagellomeres. Frons bulbously inflated, pale yellow. Rostrum threesegmented; attaining base of forelegs; pale yellow, except extreme tip dark fuscous.

Thorax: Pronotum collar-like, pale fuscous. Mesonotum pale fuscous; metanotum dark fuscous.

Legs: Basally grouped close together, with large coxae. All legs pale yellow. Two subequal tarsal segments.

Tegmen (Forewing): About twice as long as wide, without concave sculpting of any sort. $\mathrm{R}$ and Rs complete. $\mathrm{M}$ complete and reaching apical margin of wing. Cu present as clear line from wing base to anal margin of wing. Anal vein apparently absent. Base color pale yellow with three large, fuscous maculations along costal margin; three large, fuscous maculations along anal margin; and two large, fuscous maculations along apical margin. These ma- culations interspersed with numerous smaller, distinct fuscous spots.

Abdomen of Female: Pale yellow, of seven apparent segments. Dorsum of segment $V$ with dorso-caudally directed, fuscous projection. Medial point of projection extending further caudally. Dorsum of segment VI with sclerotized, obtuse dorsal projection. Apex of segment VII dorso-caudally directed to acute point. Male unknown.

Female Body Length: $3.3 \mathrm{~mm}$.

Female Tegmen Length: $3.9 \mathrm{~mm}$.

Geographical Distribution: Holotype female, was collected at Brazil: Amazonas, Manaus, by Jorge R. Arias.

Temporal Distribution: Holotype was collected on 16 October 1979.

Ecology: The holotype was taken from a Malaise trap in secondary forest on the INPA campus.

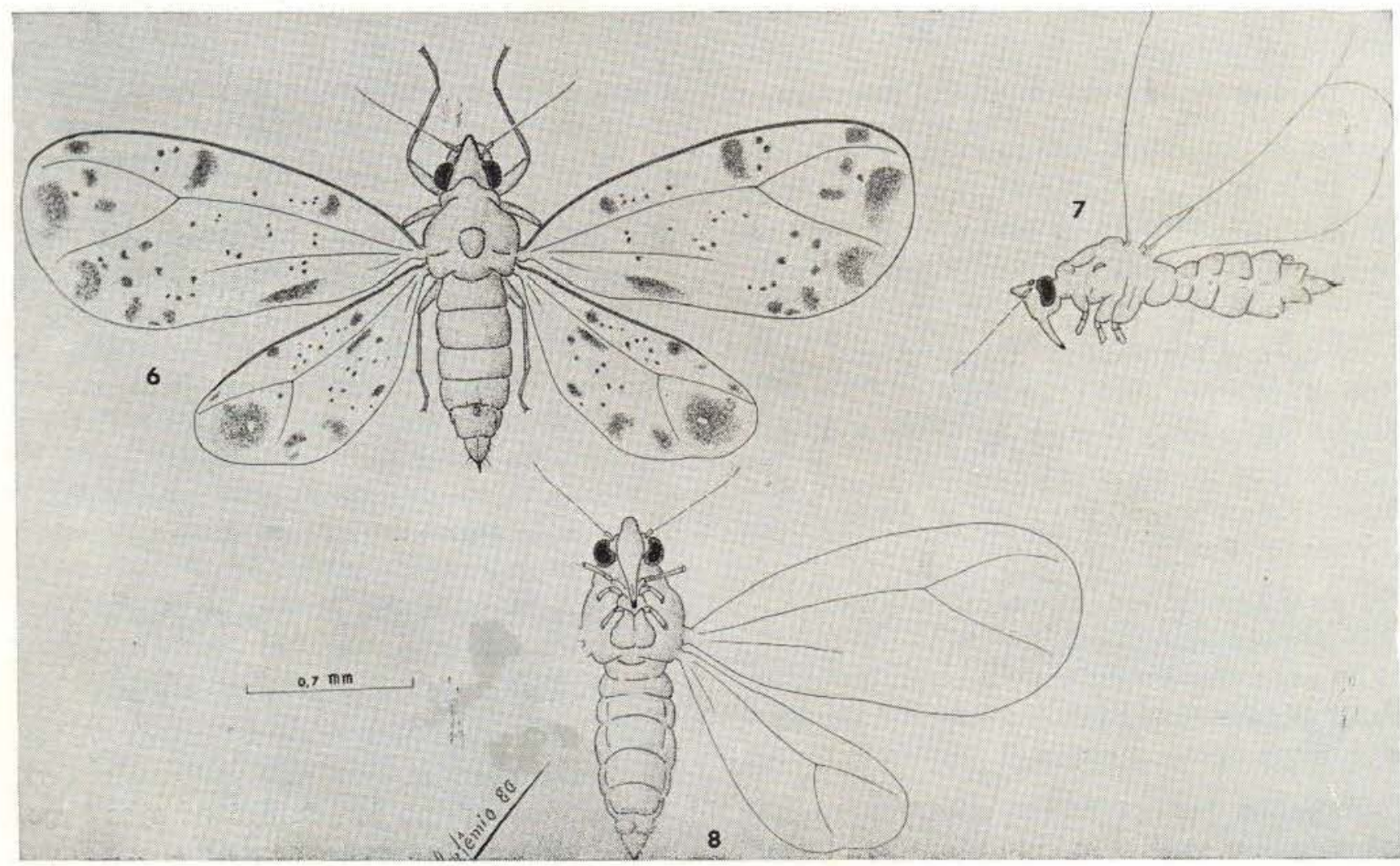

Fig. 6-8: Bakerius amazonicus n. sp.: 6) - Dorsal view of female; 7) - Lateral view of female; 8 - Ventral view of female. 


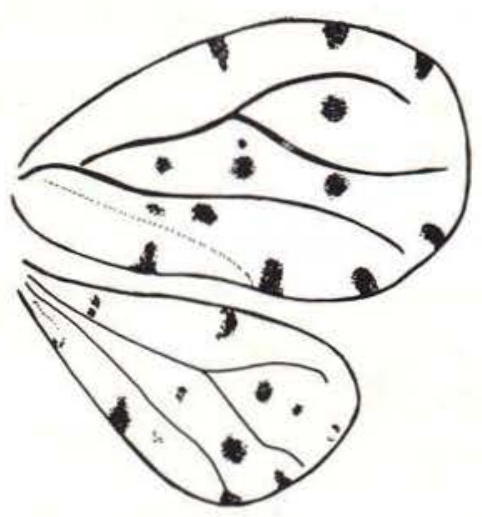

9

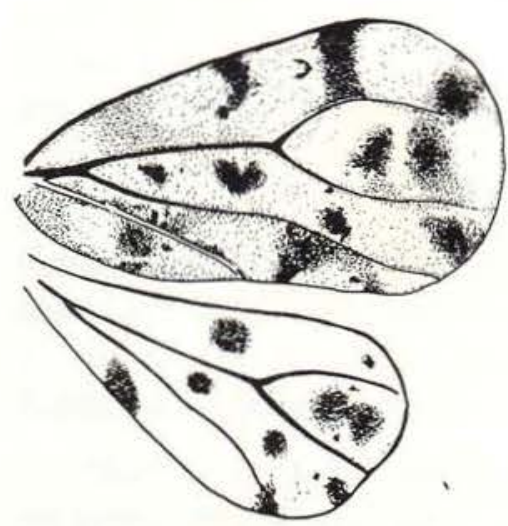

12

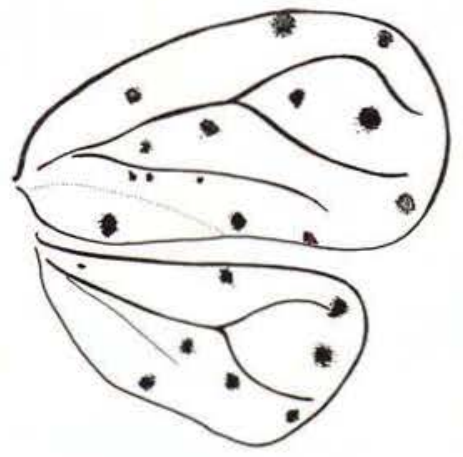

10

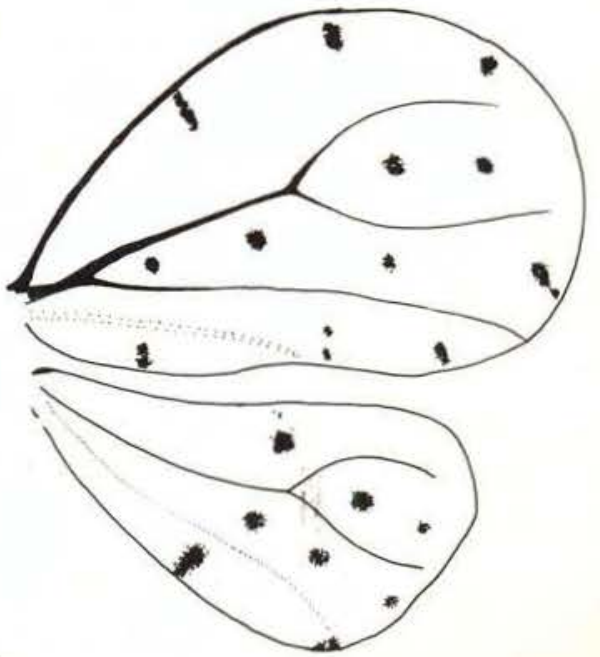

11
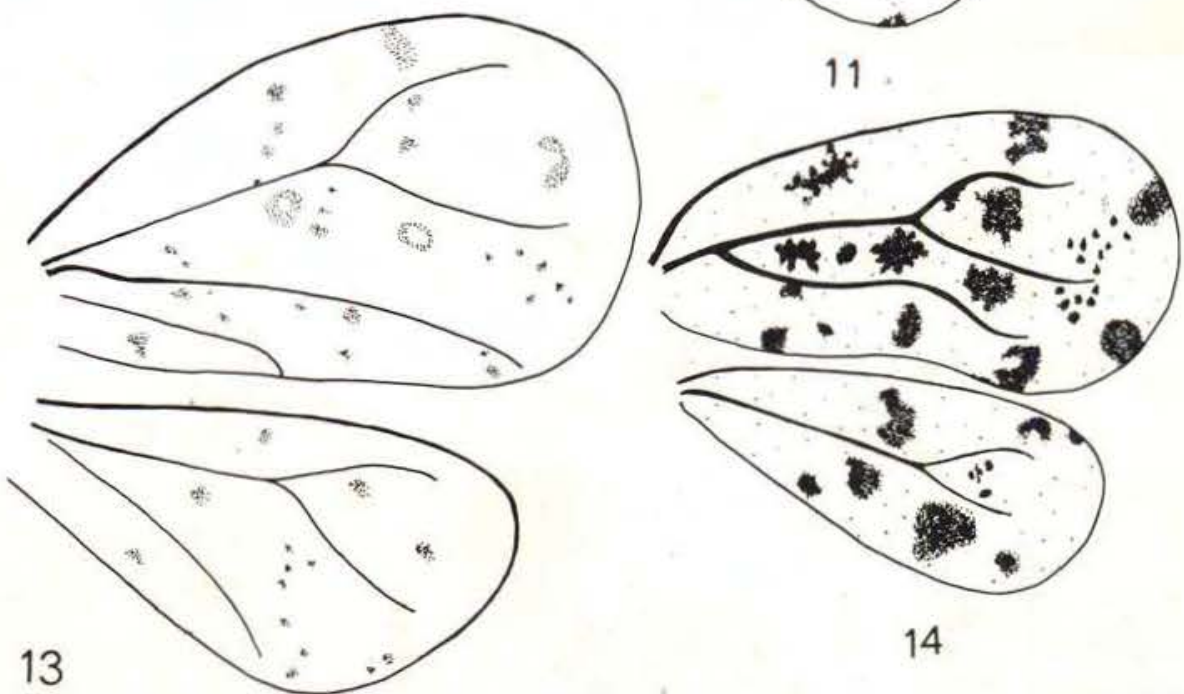

14

Fig. 9-14: Bakerius calmoni Bondar, right fore and hindwings (reproduced from Bondar, 1928); 10) - Bakerius sublatus Bondar, right fore and hindwings (reproduced from Bondar, 1928); 11) - Bakerius attennuatus Bondar, right fore and hindwings (reproduced from Bondar, 1923); 12) - Bakerius phrygilanthi Bondar, right fore and hindwings (reproduced from Bondar, 1923); 13) - Bakerius conspurcatus (Enderlein), right fore and hindwings (reproduced from Bondar, 1923); 14) - Bakerius sanguineus Bondar, right fore and hindwings (reproduced from Bondar, 1928).

Bakerius amazonicus appears to be most closely related to B. phrygilanthi and B. sanguineus, but can be separated from these, and all other species of Bakerius by the pattern of maculations of the wings, as given in the key. The name amazonicus refers to the river basin in which the type specimen was collected.

\section{ACKNOWLEDGMENTS}

We thank Artêmio Coelho da Silva for the drawings.

\section{RESUMO}

Duas espécies novas de Bakerius Bondar, 1923 são descritas do Amazonas e algumas comparações são feitas com outras espécies mais relacionadas.

\section{LITERATURE}

BONDAR, G.

1923 - Aleyrodideos do Brasil. Publ. Secret. Agric. Industr. Obr. Publ. Estado da Bahia, Sec. Pathol. Veget., Salvador. 183pp, 84 figs.

1928 - Aleyrodideos do Brasil. (2.' Contribuição). Bol. Lab. Path. Veg. Est. Bahia, 5: 1-37, 19 figs.

HEMPEL, A.

1938 - Uma nova espécie de "Aleyrodidae" (Homoptera). Arq. Inst. Biol. S. Paulo, 9: 313314,3 pls.

(Aceito para publicação em 22/01/80) 